\title{
FATIGUE STRENGTH OF WEATHERED AND DETERIORATED RIVETED PLATE-GIRDER
}

\author{
By Koei TAKENA*, Hiromichi KAWAKAMI*, Seiichi TANIFUJI** \\ and Chitoshi MIKI***
}

\begin{abstract}
In this study, a detailed review of the fatigue test results of riveted joints which have been performed in Japan, is conducted. A faigue test is carried out on a plate-girder bridge which has been used in a railroad about 70 years. The fatigue strength and the initiation and propagation behavior of fatigue cracks of weathered and deteriorated riveted plate girder is discussed.

Keywords: fatigue, riveted joint, steel structure
\end{abstract}

\section{INTRODUCTION}

Most of the bridges older than 20 years in service are riveted structures and potentially accumlated extencive fatigue damage. Therefore, adequate evaluation of the soundness of weathered and deteriorated bridges is a vital problem for bridge engineers.

The present criteria used for the fatigue design of steel bridges are mainly based on fatigue test results of newly welded joints and therefore these criteria are not satisfactory for evaluation of fatigue strength of weathered and deteriorated bridges. In the specification for railroad steel bridges of Japanese National Railways (JNR) ${ }^{1)}$ which was revised in 1983, three different set of design life lines are established for welded joints of quenched and tempered high-strength steels, for welded joints of mild steel and for non-welded joints of both types of steels, their slopes being respectively $-0.333,-0.25$ and -0.2 . For riveted joints, the design curve for category $\mathrm{B}$ of unwelded joints ( $124 \mathrm{MPa}$ at 2 million cycles) is applied. This allowable stress for riveted joints is considerably higher than ones of $\mathrm{BS} 5400^{2)}$, $\mathrm{AREA}^{3)}$ and $\mathrm{AASHTO}^{4}$.

Studies on fatigue strengths of riveted joints or riveted members are very few. Fisher et al. ${ }^{5)}$ collected the results of fatigue tests in the last 50 years in U. S. A and Europe on riveted joints and steel plates with open holes and evaluated the factors influencing the fatigue strength. From this study they concluded that the dominant factors influencing the fatigue strengths of riveted joint are mean stress, clamping force and bearing ratio (ratio of bearing stress due to rivet and allowable tensile stress) of rivets, and the fatigue strength is little influenced by tensile strengths of steel and methods of rivet hole preparation. The

* Member of JSCE, The Railway Technical Research Institute, JNR (Hikaricho, Kokubunji-city, Tokyo 185)

** Member of JSCE, Japan Construction Method and Machinery Research Institute (Oobuchi, Fuji-city, Shizuoka 417)

*** Member of JSCE, Dr. Eng., Tokyo Institute of Technology (Ookayama, Meguro-ku, Tokyo 152) 
appropriate lower limit of fatigue strength in riveted joints of which bearing ratio are less than 1.5 would be the design allowable stress for D-category joints in AREA and AASHTO specifications. Further, Fisher et al. ${ }^{5)}$ performed fatigue tests on riveted stringers of 80 years old truss bridges ; these stringers had their flanges which consist of two angles and the tested stringers contained no splices. Meanwhile Reemsnyder ${ }^{6}$ performed fatigue tests on box-section specimens containing rivet splices. However, flanges of these specimens consist of one plate.

In this study, the results of fatigue tests conducted up to this time in Japan on riveted joints and steel plates with open holes are reviewed, and the fatigue test is performed on plate girders of 70 years in service, which have flanges consisting of two angles and two cover plates and are rivet-spliced at the mid-span.

\section{REVIEW OF EXISTING FATIGUE TEST DATA}

About 200 fatigue test results ${ }^{7)}{ }^{13)}$ of riveted joints and plates with holes in about 30 years following 1955 are collected and evaluated. Large portions of these data were on steel plates with open holes.

Results of fatigue tests on plate specimens with holes made of new steels and the confidence lines for $5 \%, 50 \%$ and $95 \%$ survivals are shown in Fig. 1 . Abe et. al. carried out the fatigue tests on specimens with riveted holes taken out from an existing birdge which has been in service about 60 years. These results are also illustrated in Fig. 1. Abe et. al. reported that the edges of rivet holes in the specimens did not corrode, because these regions were covered by rivet heads. These test results are close to the lower bound of the results on the specimens made of new steels. The reason of low fatigue strengths of these specimens may lie in the fact that small test specimens employed in the laboratory are likely to have been more elaborately fabricated than the real structure. The confidence line for $95 \%$ survival of the test results of specimens of new steel is very close to the JNR B-category line which is adopted for this joint. Putting together the test results of both specimens of new and old steels, the lower bound comes close to the C-category design life line of AASHTO specifications. Fig. 2 compares the confidence lines for $5 \%, 50 \%$ and $95 \%$ survivals of the Japanese data with the data collected by Fisher et al. in U. S. A and Europe. There is little difference between the Japanese data and the U.S.A / European data.

In the design of actural structures, the bearing ratio of joint is normally set below 1.5 . Therefore,

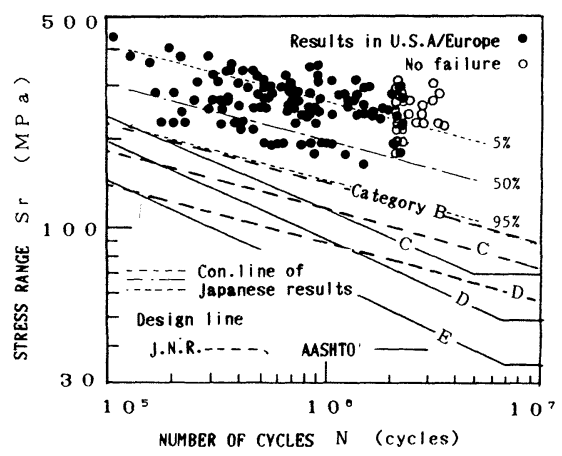

Fig. 2 Test Results of Steel Plates with Holes in Japan and U.S. A. / Europe.

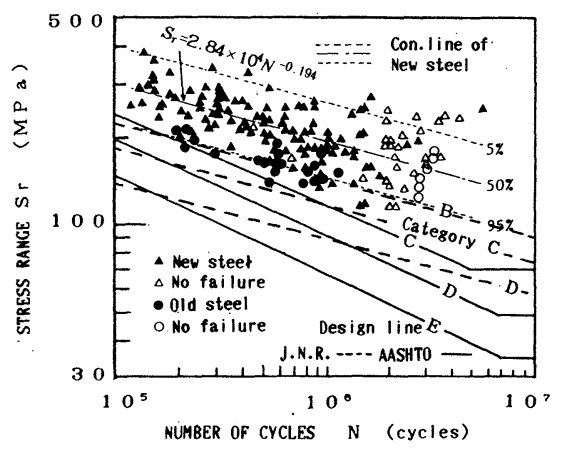

Fig. 1 Japanese Test Results of Steel Plates with Holes.

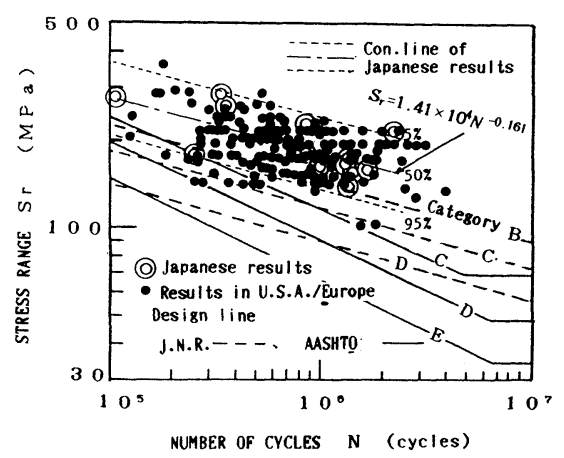

Fig. 3 Test Results of Riveted Joints performed on bearing ratio below 1.5 in Japan and U. S. A. /Europe. 
out of the test data of the Japanese riveted joints, those of which bearing ratio are below 1.5 , the confidence lines for $5 \%, 50 \%$ and $95 \%$ survivals are illustrated in Fig. 3, which includes also the test data under same condition collected in U. S. A and Europe by Fisher et al. The confidence line for $95 \%$ survival in the Japanese data comes somewhat below the B-category line of JNR, which is the allowance design curve for this joint. There is good agreement between the average of Japanese data and the average of U.S.A/European data. As for the steel plates with open holes, there is little difference between the Japanese data and the U.S. A / European data, as stated above. Taking account of these facts, it would be reasonable to consider that there is no difference between Japanese and U.S. A/European in the fatigue strength of riveted joint, either. It may be concluded from this comparison that the lower bound of the Japanese and the U.S.A/European data lies slightly below the C-category design life line of JNR.

\section{FATIGUE TEST}

\section{(1) Specimens}

A riveted deck plate girder (Fig.4) of a JNR bridge spanning the river Kannagawa on the border of Saitama and Gunma prefectures was tested. Stress measurements of this bridge under train loading were performed by Abe et. al. . ${ }^{12)}$ The maximum measured stress by the passage of old steam locomotive is about $45 \mathrm{MPa}$. Therefore, the cumulative fatigue damage in service may be negligible. The steel employed was "S 39", which is approximately equivalent to SS 41. This bridge with a span length of $12.9 \mathrm{~m}$ was constructed of two I-section girders each $1.391 \mathrm{~m}$ deep. The largest sections (E-E sections) of these girders had the flanges composed of two angles and two cover-plates. Rivet splices were connected at the midspan; webs, flange angles and upper cover-plates were connected at the midspan; and lower cover-plates were connected at two sections located at $0.49 \mathrm{~m}$ from the midspan. Rivets were not loosened. Tension flanges, except near the supporting point and partially at flange angles, were found relatively sound with little reduction of sectional area due to corrosion. On the surface of compression flange upon which there was no tie the corrosion had advanced; particularly a heavy reduction of sectional area was recognized at the boundary with splice plates.

After fatigue tests of this girder, small test pieces of riveted joints were taken, as indicated in Fig. 4, from the web splice.

\section{( 2 ) Test procedure}

Because of the heavy corrosion near the supporting points of original gerder, the supporting points for testing were set at about $0.45 \mathrm{~m}$ inside from the supporting points of original gerder. Therefore, a four-point bending test was carried out on $12.0 \mathrm{~m}$ span. The loading position was located at $0.6 \mathrm{~m}$ from midspan outside of the plate connection of the lower cover plate. Fatigue testing was done using a servo-controlled fatigue testing machine with dynamic capacity of $4 \mathrm{MN}$ under loading of 78 cycles per

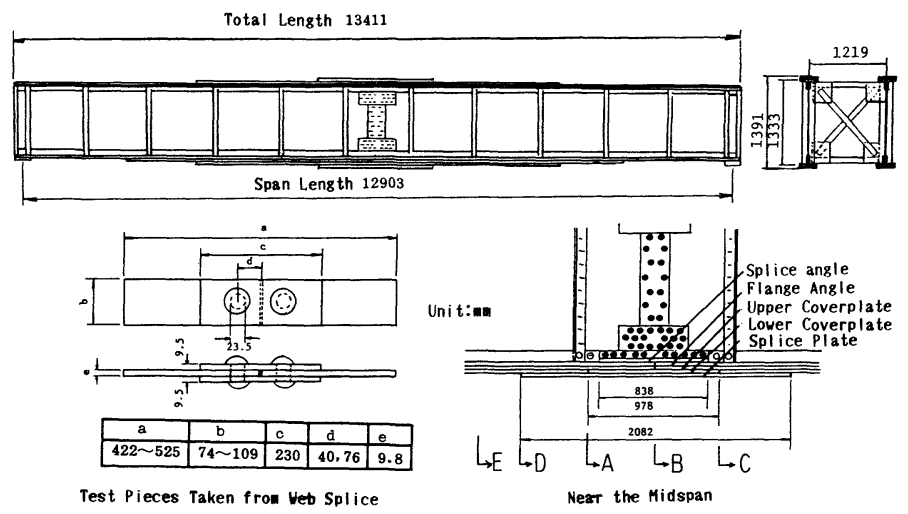

Fig. 4 Specimen 


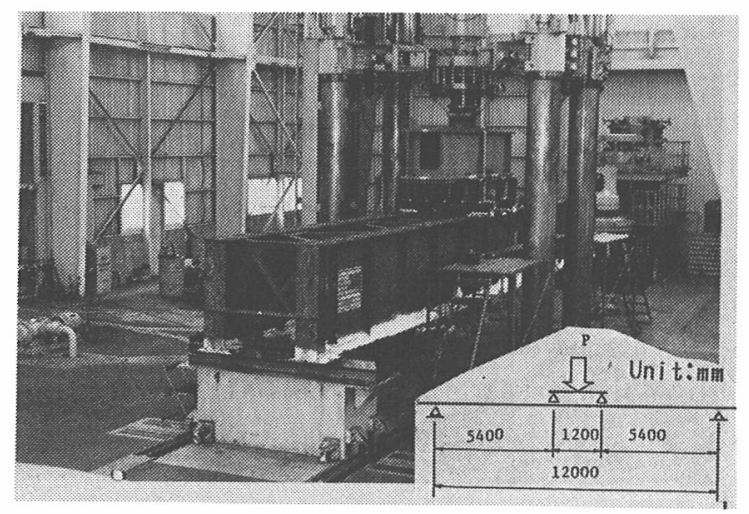

Fig. 5 Fatigue Testing Set-up.

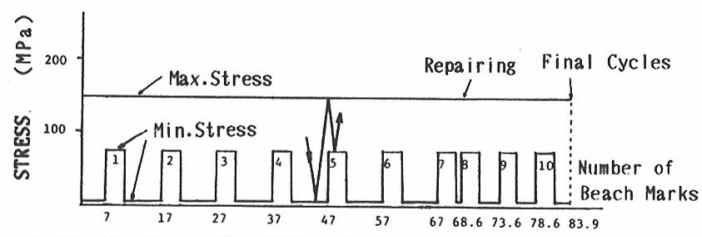

NUMBER OF CYCLES ON NORMAL LOAD ( $10^{4}$ CYCLES)

Fig. 6 Loading History.

minute with sine load waves ranging from $49 \mathrm{kN}$ to $1470 \mathrm{kN}$. Fig. 5 shows the testing set-up. In this test the stress range was halved with the minimum stress stepped up for each specific number of cycles so that beach marks could be left on the failure surface. After the test, the girder was broken up with the rivets removed in order to check for potential cracks which were not found during the test. First, visual examination and magnetic inspection were done to check for cracks in rivet holes. When cracks did not observed, a penetration test followed. Most of the potential cracks were observed by these detailed inspection.

The joint specimens cut out of the web were submitted to fatigue testing at stress ratio 0 .

\section{(3) Outline of test results}

The nominal stress range for the net section of the largest section (E-E section) was $131 \mathrm{MPa}$. Measured stress range for a rivet-free section in the tension flange at midspan was $111 \mathrm{MPa}$. This stress range, converted to the value for net section with rivet holes, will be equal to $130 \mathrm{MPa}$, showing good agreement with the calculated value. The bearing ratio of this riveted splice-joint was 1.22.

Fig. 6 illustrates the loading history. At about $10^{4}$ cycles a crack $\left(L_{A}\right.$ crack) initiated near the edge of a corroded groove of the horizontal angle leg (reduction of sectional area was about a half that of the original shape) at the end of the splice angle in the vicinity of A-A section of the left girder. Photo 1 shows the ultimate state of this crack. This crack was observed to coalesce into new ones which developed later.

At $68.6 \times 10^{4}$ cycles, the crack near A-A section of the right girder had grown so large that the testing was interrupted. As seen from Photo 2, the right girder then had all its flange cut through, with the crack

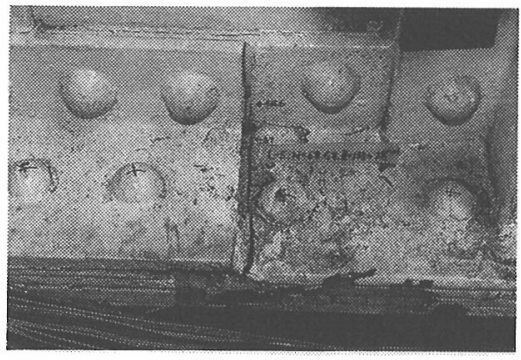

Photo 1 Crack which initiated from Edge of Corroded Grove (Crack $L_{\Lambda}$ ).

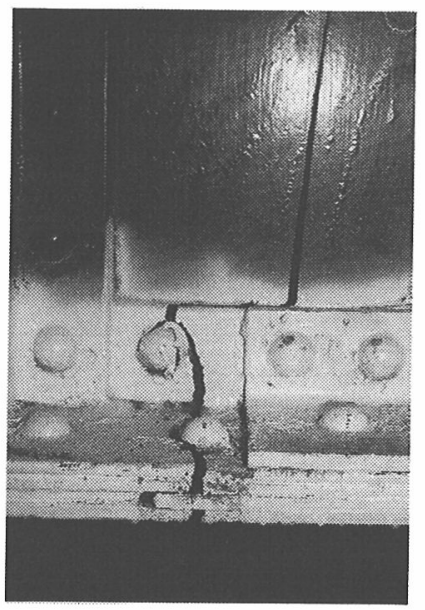

Photo 2 Crack which penetrated through Lower Flange (Crack $R_{A}$ ).

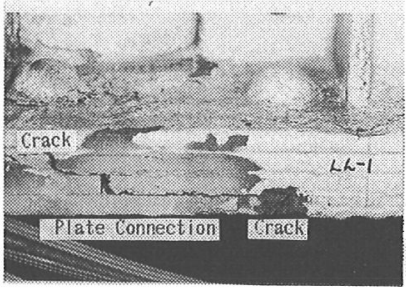

Photo 3 Crack $L_{A}$. 


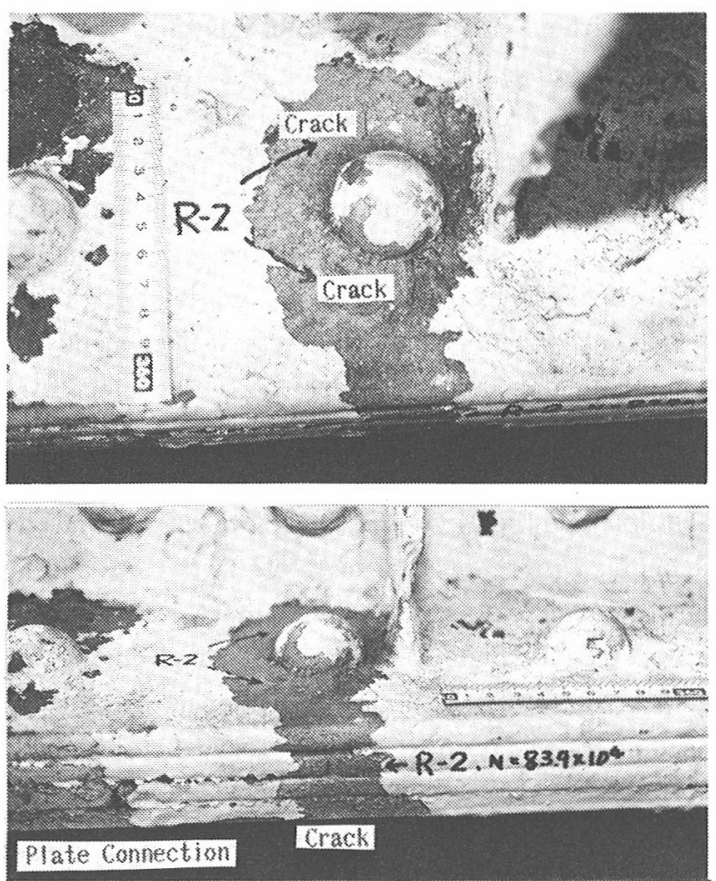

Photo 4 Crack found by Stripping Paint Film $\left(R_{c}\right)$.

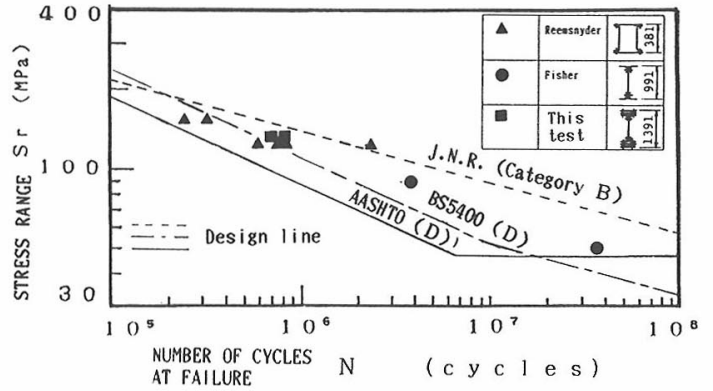

Fig. 7 Test Results of Riveted Members.

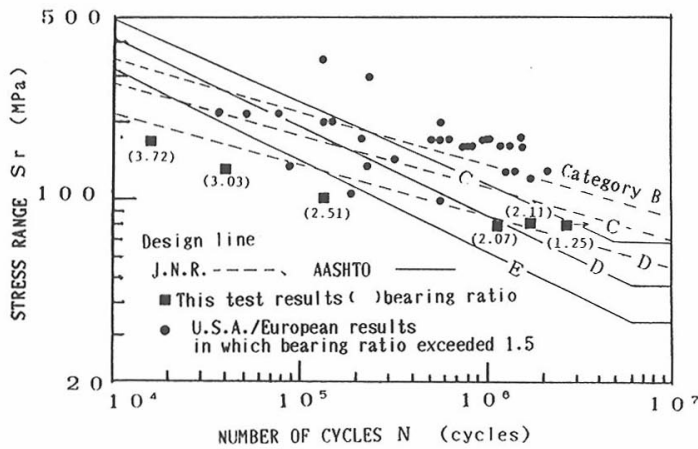

Fig. 8 Test Results with Bearing Ratio Varied.

advancing up to near-half of the web $\left(R_{A}\right.$ crack). Photo 3 indicates that in the left girder the cracks on the upper cover plate and the splice plate had developed respectively from the rivet holes in two symmetric sections with regard to the connection of the lower cover plate $\left(L_{A}\right.$ crack). The splice plate completely failed, while the upper cover plate was not cut through. As shown in Photo 1, the crack of one flange angle propagated up to about $1 / 3$ length of the vertical leg, but no crack was observed on the other flange angle opposed to it across the web. This seems to be an accelerated failure, because no crack was observed in a visual examination which was done $1.6 \times 10^{4}$ cycles earlier.

Fatigue testing was resumed after the repairing of failure sections by splices with high-strength bolts. At $79.3 \times 10^{4}$ cycles, a crack was observed to initiate from a rivet hole of the splice plate near $\mathrm{C}-\mathrm{C}$ section of the left girder ( $L_{c}$ crack). At $83.9 \times 10^{4}$ cycles, with the flange failure and the crack propagating up to half the web, the testing was terminated. Immediately thereafter, the right girder had its paint film stripped at a symmetric position to the failed section of the left girder, revealing that, as indicated in Photo 4, the surface of the flange had been cracked and the upper cover plate had been cracked up to the end of its plate ( $R_{C}$ crack). In the presence of painting film, no crack can yet been revealed in such a case. The painting film was 7 years and 5 months old.

\section{(4) Fatigue strength}

The relationships between number of cycles to failure and stress range of riveted details in this test is illustrated in Fig. 7, in which the number of cycles to halve the stress range for the purpose of leaving beach marks on the failure surface is not included. For the comparison, the design life curves for riveted joints in JNR, AASHTO and BS 5400 specifications and other fatigue test results of large size riveted member are also given. The results of this test are close to the other results of riveted members; and these results approximately match the lower bound of fatigue test results of small test specimens in Fig. 3 . The results of riveted members come below JNR design life curve; and below the BS 5400 one in a high stress range region. In the tests of aged and deteriorated stringers undertaken by Fisher et al., fatigue cracks initiated from rivet holes in the equi-moment section with no rivet splice and the stress condition at rivet 
splice was severer than the stress condition at riveted detail with no rivet splice. From this fact, it seems that the fatigue life of rivet splice closely follows the AASHTO design life curve for D-category joints.

After this fatigue test, specimens cut out of the web splice were submitted to fatigue tests. These specimens had various bearing ratios. The test results were illustrated in Fig. 8 . The results of test reviewed by Fisher et al. with loosened rivets and the bearing ratio amounting to more than 1.5 and the AASHTO design life lines are also given in Fig. 8. The results of this fatigue test are lower than the AASHTO E-category design line when the bearing ratio exceeded 2.5 , and barely equivalent to the D-category design line when the bearing ratio dropped to about 2. The rivets of these test specimens are not loosened. It is known from this that the fatigue strength considerably decreases as the bearing ratio increases.

(5) Initiation and propagation of fatigue crack

The results of crack observations are summarized in Table 1 and Fig. 9. In the figure the outside and the inside mean respectively the inside and the outside of the bridge with respect to the web. A, $P_{3}, P_{2}$, and $P_{1}$ represent the flange angle, the upper cover plate, the lower cover plate and the splice plate respectively. Near A-A and C-C sections at the connections of the lower cover plate, cracks were found during the fatigue test ( $L_{A}$ crack, $R_{A}$ crack, $L_{C}$ crack and $R_{C}$ crack). Near B-B section at the midspan of the right girder a single tiny crack of less than $1 \mathrm{~mm}$ long was discovered at the rivet hole edge by the crack observation after the fatigue test $\left(R_{B}\right.$ crack). Near D-D section at the end of the splice plate, the same observation revealed a crack in the left girder $\left(L_{D}\right.$ crack). These cracks in tension flanges invariably initiated from the rivet hole closest to the plate connection of the spliced part and from the position where the sectional area had been reduced to less than one half of the original area on account of corrosion, but no cracking was observed at other rivet holes. In the compression flanges, cracks initiated from four spots of heavily corroded cover plates at the end of the splice plate.

Photos and sketches of failure surfaces of $R_{A}$ crack, $L_{c}$ crack, $R_{C}$ crack and $L_{A}$ crack are respectively given in Figs. 10, 11, 12 and 13. Fatigue cracks which initiated from rivet holes and led to failures of all the flange plates and some of the webs are identified as $R_{A}$ crack and $L_{C}$ crack.

The beach marks of $R_{A}$ crack were found to be three on the left side of a inside rivet hole of $P_{1}$ plate, two on the right side of it, and one with broad width on the right side of an outside rivet hole of $P_{1}$ plate. In the outside flange angle a broad beach mark was observed on the right side of a rivet hole. These broad beach marks are evidence that the crack rapidly propagated even when the load range was reduced to half. $P_{3}$ plate and the inside flange angle exhibited no beach mark. Considering the number, spacing and breadth of beach marks, the fatigue crack is likely to initiate and propagate in the following process. First, a fatigue crack initiates at the left top edge of a inside rivet hole of $P_{1}$ plate. Next a crack initiates at the right bottom edge of the same hole. Then the left crack arrives at the left edge of the plate, while the right crack

\begin{tabular}{|c|c|c|c|c|c|c|c|c|c|}
\hline \multicolumn{3}{|c|}{ Section of Crack } & \multirow{2}{*}{ Name } & \multirow{2}{*}{\begin{tabular}{|c|}
$\begin{array}{l}\text { Number of } \\
\text { Stress } \\
\text { Brocks }\end{array}$ \\
7
\end{tabular}} & \multirow{2}{*}{$\begin{array}{l}\begin{array}{c}\text { Number of } \\
\text { Beach } \\
\text { Marks }\end{array} \\
7\end{array}$} & \multirow{2}{*}{ 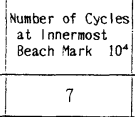 } & \multirow{2}{*}{$\begin{array}{l}\begin{array}{c}\text { Cycles at } \\
\text { Find ing } \\
\text { Crack } 10^{4}\end{array} \\
※ 1\end{array}$} & \multirow{2}{*}{\begin{tabular}{|l|}
$\begin{array}{l}\text { Cycles at } \\
\text { Failure } \\
10^{4}\end{array}$ \\
68.6
\end{tabular}} & \multirow{3}{*}{\begin{tabular}{l}
\multicolumn{1}{|c}{ Note } \\
$\begin{array}{l}\text { Reinforced by } \\
\text { High strength } \\
\text { Bolts after } \\
\text { Failure }\end{array}$ \\
\end{tabular}} \\
\hline \multirow{4}{*}{$\begin{array}{l}\text { Cracks } \\
\text { near } \\
\text { Plate- } \\
\text { Connection } \\
\text { of Lower } \\
\text { Coverplate }\end{array}$} & \multirow{2}{*}{$\begin{array}{l}\text { A-A } \\
\text { Section }\end{array}$} & $\begin{array}{l}\text { Left } \\
\text { Girder }\end{array}$ & & & & & & & \\
\hline & & $\begin{array}{l}\text { Right } \\
\text { Girder }\end{array}$ & $R_{\mathrm{A}}$ & 7 & 4 & 37 & - & 68.6 & \\
\hline & \multirow[b]{2}{*}{$\begin{array}{l}\text { C-C } \\
\text { Section }\end{array}$} & \begin{tabular}{|l} 
Left \\
Girder \\
\end{tabular} & $L_{C}$ & 10 & 6 & 47 & 79. 3 & 83.9 & \\
\hline & & $\begin{array}{l}\text { Right } \\
\text { Girder }\end{array}$ & $R_{C}$ & 10 & 7 & 37 & 83.9 & - & $\begin{array}{l}\text { Found by } \\
\text { Stripping } \\
\text { Paint Filim }\end{array}$ \\
\hline \multicolumn{2}{|c|}{$\begin{array}{l}\text { Crack Near } \\
\text { B-B Section } \\
\text { at Midspan }\end{array}$} & $\begin{array}{l}\text { Right } \\
\text { Girder }\end{array}$ & $R_{B}$ & 10 & - & - & - & - & $\begin{array}{l}\text { SmalICrack } \\
\text { Below Imm } \\
\text { Found After } \\
\text { Girder Broken }\end{array}$ \\
\hline \multicolumn{2}{|c|}{$\begin{array}{l}\text { Crack Near } \\
\text { D-D Section }\end{array}$} & $\begin{array}{l}\text { Left } \\
\text { Girder }\end{array}$ & $L_{0}$ & 10 & 7 & 37 & - & - & $\begin{array}{l}\text { Found After } \\
\text { Girder Broken }\end{array}$ \\
\hline
\end{tabular}




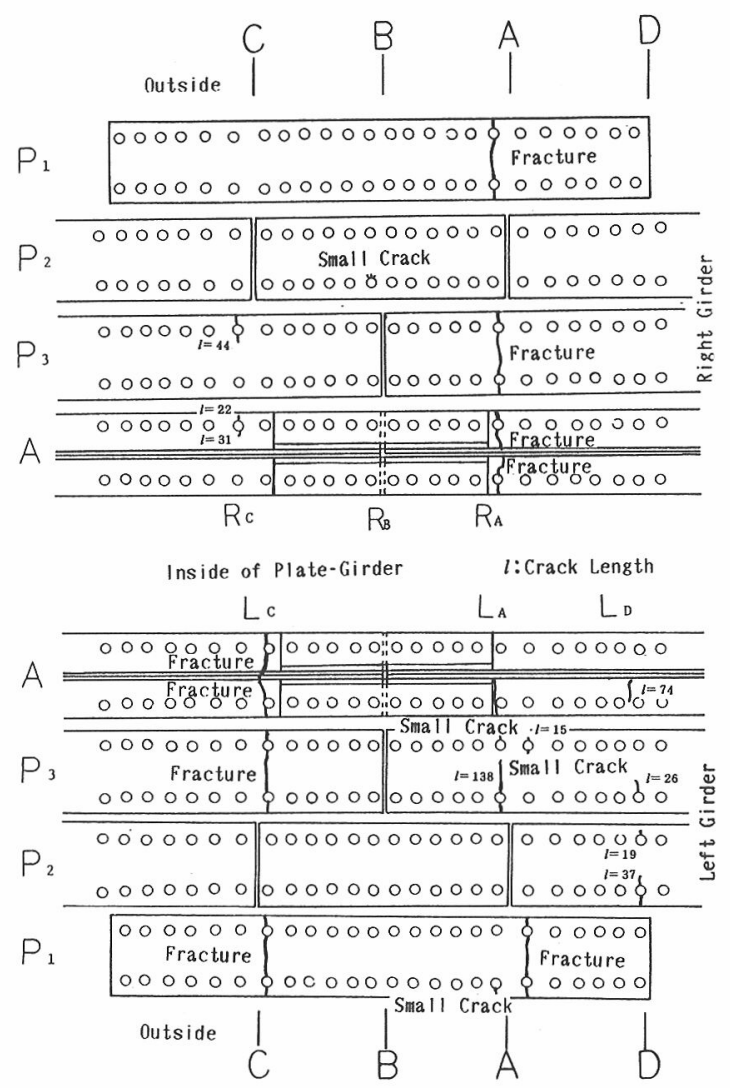

Fig. 9 Results of Crack Observations.

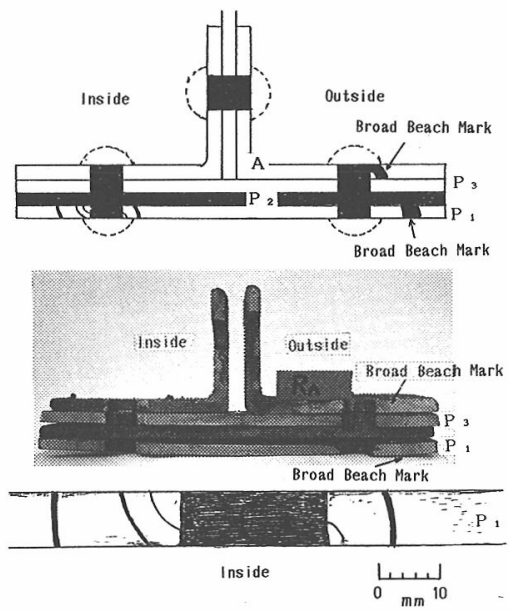

Fig. 10 Failure Surface of Crack $R_{A}$

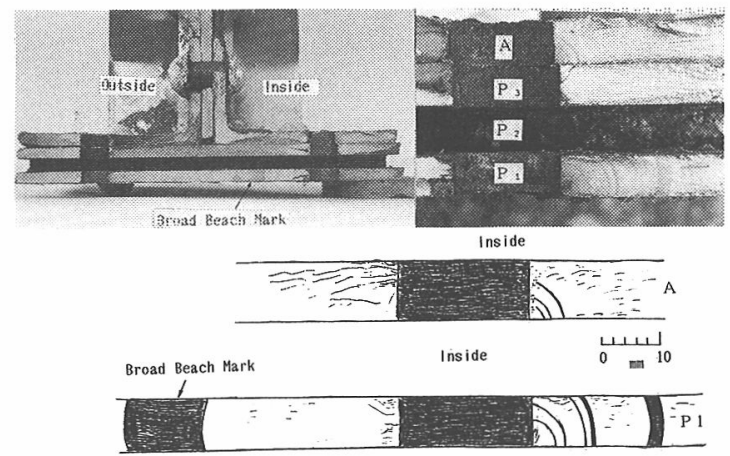

Fig. 11 Failure Surface of Crack $L_{c}$.

rapidly propagates beyond the outside rivet hole until $P_{1}$ plate is wholly broken, leaving the last beach mark. In the outside flange angle, by the time that $P_{1}$ plate almost fails, a crack starts form the right bottom edge of a rivet hole and rapidly causes a failure, leaving a broad beach mark. And at the $1.6 \times 10^{4}$ cycles after final half-reduced load the inside flange angle and $P_{3}$ plate quickly come to a failure. Number of half-reductions of the load is 7 in total till the cracks are repaired and the total number of beach marks recognized on the failure surface is four. From this it follows that the first beach mark emerged at $37 \times 10^{4}$ cycles.

The beach marks of $L_{c}$ crack [Fig. 11] were found to be five on the right side of a inside hole of $P_{1}$ plate, one with broad width the left side of it, and three on the right side of a hole in the inside flange angle. There were no beach marks recognized on the $P_{3}$ plate and on the outside flange angle. From the detailed observation of beach marks, the initiation and propagation behavior of fatigue cracks in this failure surface are considered as follows. A fatigue crack happens at the right bottom corner edge of a inside hole of $P_{1}$ plate, leading to a failure of the right section. By that time, a crack starts from the left side of the hole, causing a sudden failure of the whole section of $P_{1}$ plate leaving a broad beach mark. The beach marks on the right side of a hole of the inside flange angle are three and the half-reductions of the load after repairing of A-A section are three, indicating that a crack has started from the right bottom edge a short time before the repairing. This crack propagated with relatively stable manner up to the final half-reduction of the load and then quickly advanced to a failure during the succeeding $5.3 \times 10^{4}$ cycles, and in the meantime the outside flange angle and $P_{3}$ plate came to a sudden failure. In other words, after the time that the whole section $P_{1}$ plate had failed, the cracks in the other elements of the flange suddenly extended, causing a failure of these elements. The half-reductions of the load of these cracks were ten and 


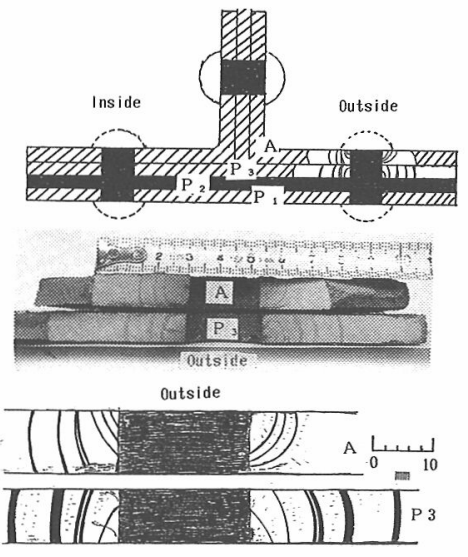

Fig. 12 Failure Surface of Crack $R_{C}$.

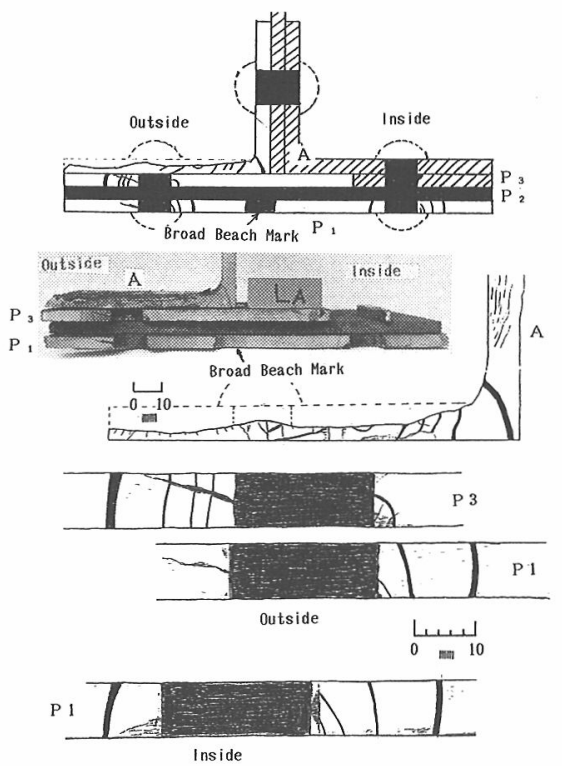

Fig. 13 Failure Surface of Crack $L_{A}$.

the beach marks observed were six in total. Therefore it can be said that the innermost beach mark has emerged at $47 \times 10^{4}$ cycles.

$R_{C}$ crack [Fig. 12] is one which was found just after the fatigue test is interrupted and it can be exposed with removal of the paint film. The beach marks revealed were seven on the left side of a hole in the outside flange angle ; three on the right side of it ; five on the left side of a outside hole of $P_{3}$ plate ; and six on right side of it. No cracking occurred in $P_{1}$ plate which had been most heavily stressed. From the observation of these beach marks, it can be speculated that cracks initiated nearly at the same time before $37 \times 10^{4}$ cycles at the left top edge of a hole in the outside flange angle, and at the left and the right bottom edge of a hole in $P_{3}$ plate, followed with a little delay by a crack at the right top edge of a hole in the flange angle. And just before the test was finished, the crack on right side of a outside hole of $P_{3}$ plate arrived to the right end of $P_{3}$ plate. These cracks propagated with relatively stable manner.

Detailed observations of fatigue failure surface lead to the following conclusions: (a) Fatigue cracks can be initiated from rivet holes of any one of the plates constituting the flange, but it is a little more liable to start from rivet holes of the bottom most plate: (b) the position of crack initiation is at the edge of a rivet hole, not at the inner surface between plates that Fisher et. al. reported. ${ }^{5)}$ (c) the crack propagates with relatively stable manner up to a failure of one side of a plate, but thereafter the propagation is accelerated. This is supposedly because the clamping force of rivet decreases with a failure of one side of plate, resulting in decreasing of fricitional force between plates, and in consequence the crack tips comes be extremely stressed.

$L_{A}$ crack (Photo. 1 and Fig. 13) is differently characterized from the above three types of cracks. One feature is that the crack in the flange angle starts not from the rivet hole but from a corroded surface. Another feature is that $L_{A}$ crack starts from the rivet holes in two symmetric sections with respect to the connection of $P_{2}$ plate, whereas the other types invariably start from the rivet holes in the same section (Fig.9). In the outside flange angle a number of cracks initiated from notches on the rough irregular surface of its horizontal leg where the sectional area had been reduced to half the original area as a result of corrosion, and they coalesced into one, leaving seven beach marks which were as many as the load reductions with no cracks starting from rivet holes. In the inside flange angle no cracks initiated. $L_{D}$ crack in the flange angle behaves just like $L_{A}$ crack in the flange angle; that is, the crack initiated at the surface 
where the sectional area has been corroded to less than half the original area.

Observations of failure surface of $L_{A}$ and $L_{D}$ cracks indicate that (a) when the sectional area has been reduced to a half by corrosion, as the stress concentration results in being large at the notches on the rough irregular surface, a crack is more liable to start there than in the riveted part and (b) a crack which initiates from the corroded surface behaves more stably than one initiated from the riveted part and the former is a little easier to detect than the latter, accordingly more likely to be detected and repaired at the time of inspection in service.

\section{CONCLUSIONS}

Major findings from this study are as follows;

(1) There is little difference between the results of fatigue tests of steel plate with open holes in Japan and U. S. A / Europe. The lower bound of these data is close to the JNR B-category design curve and AASHTO C-category design curve.

(2) The lower bound in the results of fatigue tests performed on small specimens of riveted joints in the past and the results of this study comes close to JNR C-category design curve and AASHTO D-category design curve.

(3) In this test, among the elements of the flange, i. e. two angles and two cover plates, an angle had its sectional area reduced to about half by corrosion, but this reduction of area hardly affected the total fatigue strength of the riveted girder.

(4) Fatigue crack is liable to initiate from the rivet hole edge closest to plate connection where stress concentration is large. No crack starts from the other holes. The crack can initiate from any of the plates constituting the flange, but the bottom-most plate is a little more likely to be first one to develop a crack.

(5) When the sectional area is reduced to a half by corrosion, as the stress concentration becomes large on the rough irregular surface, the crack becomes more liable to start from the notches on the corroded surface than from the rivet hole.

(6) When the bearing ratio increases, the fatigue strength decrease significantly. In this test, the fatigue strength decreased below the design life line for E-category joints of AASHTO, when the bearing ratio exceeded 2.5 .

(7) A crack which initiates from the rivet hole behaves with stable manner up to a failure of one side of a plate, but thereafter it propagates fast. This is supposedly because the clamping force of rivet decreases with a failure of one side of the plate, resulting in decreasing of frictional force between plates, and in consequence the crack tip comes to be significantly stressed.

It should be noted that the fatigue tests of the riveted girder and test specimens cut out of it were executed using the testing facilities of the Honshu Shikoku Bridge Authority at the Japan Construction Method and Machinery Research Institute and Tokyo Institute of Technology, respectively. Sincery gratitude is expressed to Mr. K. Asakawa and Mr. Y. Eguchi for the former test, to Mr. Mori, for the latter test, and to Mr. M. Abe for cooperation in literature survey.

\section{REFERENCES}

1) JSCE : The Specification for Steel Railway Bridges, 1983.3 (in Japanese).

2) BS 5400 Part $10:$ Steel, Concrete and Composite Bridges, Code of Practice for Fatigue, 1980.

3) AREA : Standard Specifitions for Raiway Bridges, 1985.

4) AASHTO : Standard Specifications for Highway Bridges, 1977.

5) Out, J. M. M., Fisher, J. W. and Yen, B. T. : Fatigue Strength of Weathered and Deteriorated Riveted Members, Technical Report 483(84), Fritz Engineering Laboratory, Lehigh University, 1984.10.

6) Reemsnyder, H. S. : Fatigue Life Extension of Riveted Connections, Journal of the Structural Division $101: 2591,1975.12$.

7) Konishi, I. : Fatigue Strength of Riveted Joints Made of Structual High Strength Steels, Journal of JSCE, Vol. 45, No. 9, 1955 
(in Japanese).

8) Komatsubara, M., Tajima, J. and Ohmiya, K. : Fatigue Tests of Tension Bolted Joints, Railway Technical Reaseach Report, No. 232, 1961.7 (in Japanese).

9) Tajima, J. : Static and Fatigue Strengths of Riveted and Bolted Joints Made of High Tensile Strength Steels, Technical Reaseach Report, No. 283, 1962.4 (in Japanese).

10) Kansai Study Group about High Tensile Strength Steels : Study on Fatigue Strength of High Tensile Strength Steels, Journal of JSCE, 1969. 11 (in Japanese).

11) Abe, H., Inaba, N. and Eguchi, Y. : Fatigue Strength of Corroded Steel Material, Structural Design Data, No. 34, 1973.6 (in Japanese).

12) Abe, H. and Abe, M. : Fatigue Strength of Railway Bridge Recieved by Repeated Train Load, Structural Design Data, No. 57, 1979.3 (in Japanese).

13) JSCE : Report on the Steel Superstructure of Honshu-Shikoku Bridges, 1973.3 (in Japanese).

(Received October 30 1986) 